\title{
An isotope study of the sources of nitrate in groundwater in Malta
}

\author{
Tim H.E. Heaton ${ }^{a}$, Marianne E. Stuart ${ }^{b}$, Manuel Sapiano ${ }^{c}$, Miriam Micallef Sultana ${ }^{\mathrm{c}}$ \\ ${ }^{a}$ British Geological Survey, Nottingham NG12 5GG, England \\ ${ }^{b}$ British Geological Survey, Wallingford, OX10 8BB, England \\ c Malta Resources Authority, Marsa, MRS 9065, Malta
}

\section{SUMMARY}

Levels of nitrate in Malta's groundwater are high. Median concentrations in the main sea-level aquifers of Malta and Gozo are 14 and $10 \mathrm{mg} \mathrm{NO}_{3}-\mathrm{N} \mathrm{L}^{-1}$, respectively, and even higher in the younger groundwaters of the perched aquifers on Malta $\left(37 \mathrm{mg} \mathrm{NO} \mathrm{N} \mathrm{N} \mathrm{L}^{-1}\right)$. The wide variations in groundwater nitrate concentration are not due to denitrification, as ${ }^{15} \mathrm{~N} /{ }^{14} \mathrm{~N}$ and ${ }^{18} \mathrm{O} /{ }^{16} \mathrm{O}$ analyses of 47 samples from the three aquifer types found evidence for this process in only two samples. $90 \%$ of the groundwater nitrate samples had $\delta^{18} \mathrm{O}$ values in the range +3.1 to $+6.1 \%$, which correspond exactly to those expected for nitrate formed by microbial processes in the presence of Maltese surficial waters $\left(\delta^{18} \mathrm{O}\right.$ of $\mathrm{H}_{2} \mathrm{O}$ typically -5.3 to $-4.3 \%$ ). The $\delta^{15} \mathrm{~N}$ values of these groundwater nitrate samples, +7.7 to $+11.7 \%$, were compared with those of a wide variety of potential nitrate sources in Malta (fertilizers, sewage, manure and soils). The closest correspondence was found for the organic $\mathrm{N}$ in cultivated soils $\left(+6.0\right.$ to $+11.2 \%$ ). These relatively high $\delta^{15} \mathrm{~N}$ values for soils may reflect greater 'openness' to $\mathrm{N}$ among soils with a low $\mathrm{C} / \mathrm{N}$ ratio and a long history of cultivation. While the isotope data support soil nitrification as the source for nitrate in the groundwaters, they do not rule out direct leaching of manure-derived nitrate as a source. 


\section{Introduction}

The Republic of Malta is largely comprised of two islands, Malta $\left(246 \mathrm{~km}^{2}\right)$ and Gozo (67 $\mathrm{km}^{2}$ ), and with a population of 412,000 is one of the most densely populated countries in the world (DOIM, 2009). 23\% of the land is built upon, and $60 \%$ of the remaining area is used for agriculture (NSO, 2006). The combined domestic, tourist, industrial and farming activities place strong demands on water supplies, with Malta having one of the world's highest Water Competition Indexes (Mangion et al. 2005). The demand is met predominantly by groundwater abstraction $(56 \%)$ and seawater desalinization (34\%), with more limited use of harvested rainwater runoff and treated sewage effluent (Sapiano et al., 2006). Over half of the water put into public supply is desalinated seawater. But whilst this provides a reliable supply of good quality water, the high cost of desalinisation, and its dependence on imported oil, means that groundwater continues to be a vital resource.

The utility of this groundwater resource, however, is being compromised by poor chemical quality: especially seawater intrusion (some parts of aquifers having chloride levels above WHO limits) and high levels of nitrate (MEPA, 2006). Average nitrate concentrations in the main aquifers sampled as part of the present study exceed the $11.3 \mathrm{mg} \mathrm{NO}_{3}-\mathrm{N} \mathrm{L}^{-1}$ limit imposed by the European Union's (EU) Nitrate Directive and Water Framework Directive, with nitrate levels in some of the minor groundwater bodies reaching levels more than six times the EU quality standard (EC, 1991; EU, 2000; EEA, 2008). As part of Malta's programme to address this problem, the British Geological Survey and the Malta Resources Authority conducted a preliminary study on the identification of the sources of nitrate contamination in groundwater in Malta. Geochemical aspects of groundwater movement are reported elsewhere (Stuart et al., 2010); the present work reports on the results of the isotope study of nitrate.

\section{Malta's groundwater}

\subsection{Hydrology}

A schematic section of the main island of Malta is shown in Figure 1, and illustrates features of the geohydrology relevant to both Malta and Gozo. The Tertiary geology is essentially made up of two limestone sequences separated by an impermeable clay-marl: the Blue Clay (Pedley et al., 1976; Figure 1).

\subsubsection{Perched aquifers}

Above the Blue Clay, the top of the succession is formed by the Upper Coralline Limestone, mainly present on the west side of Malta and the east side of Gozo. The impermeabililty of the clay supports perched groundwater within the overlying limestone. Faulting and erosion means that this groundwater is present as several hydrologically separate perched aquifers. These provide water for agricultural use from shallow boreholes or natural springs.

\subsubsection{Mean Sea Level (MSL) aquifers}

Stratigraphically below the Blue Clay, Globigerina and Lower Coralline limestones constitute the major rock formations of the islands. Over most parts of both Malta and Gozo the Lower Coralline Limestone supports a classic 'Ghyben-Herzberg' lens of fresh water floating on sea-water (Figure 1). The fresh water is abstracted from boreholes and, in particular, from long galleries which take water from the top of the lens and maintain its water table at just a few metres above mean sea level (Figure 1). These two 'Mean Sea Level' aquifers ('Malta MSL' and 'Gozo MSL') supply over $80 \%$ of Malta's groundwater, for both potable and agricultural use, with the 
Malta MSL aquifer being by far the most important (Bakalowicz and Mangion, 2003; Sapiano et al., 2006).

\subsection{Groundwater residence time and chemistry}

\subsubsection{Perched aquifers}

In agreement with the hydrological settings, tritium and $\mathrm{SF}_{6}$ data suggest that the perched aquifers contain relatively young groundwater (Bakalowicz and Mangion, 2003; Stuart et al., 2010) This was confirmed by the presence of $E$. Coli, often at high concentrations, in 10 of the 12 perched aquifer sources sampled in this study (Stuart et al., 2010). The major ion chemistry is predominantly $\mathrm{Ca}+\mathrm{Mg}$ bicarbonate, but also with high concentrations of $\mathrm{Na}$ and $\mathrm{Cl}$ (median ca. $250 \mathrm{mg} \mathrm{Cl} \mathrm{L}^{-1}$ ) in ratios close to that of seawater (Table 1). This is presumed to derive mainly from sea salts in rainfall concentrated by evaporation (Stuart et al., 2010), or by minor sea water contamination where perched aquifers are close to sea level (Sapiano et al., 2006).

\subsubsection{Mean Sea Level (MSL) aquifers}

Since the islands rise to a maximum altitude of $239 \mathrm{~m}$ above sea level, the MSL aquifers are overlain by a thick unsaturated zone, typically from 40 to $120 \mathrm{~m}$ for boreholes sampled in this study (Stuart et al., 2010). In western parts of Malta, and over a large area of Gozo this zone is capped by the Blue Clay and Upper Coralline Limestone. Estimates of groundwater age based on rock properties, tritium, CFC and SF6 data are variable, with maximum residence times in the unsaturated plus saturated zones of a hundred years or more, and the probability that water in the Gozo MSL aquifer is older due to the greater extent of low permeability Blue Clay cover on Gozo (Bakalowicz and Mangion, 2003; Stuart et al., 2010). In contrast to the perched aquifers, $75 \%$ of the boreholes tapping MSL aquifers had no detectable E. Coli. (Stuart et al., 2010). Waters in the MSL aquifers have bicarbonate concentrations comparable to the perched aquifers, but with higher $\delta^{13} \mathrm{C}$ values and $\mathrm{Mg} / \mathrm{Ca}$ and $\mathrm{Sr} / \mathrm{Ca}$ ratios than in the perched aquifers, suggesting more evolved incongruent solution of carbonate (Stuart et al., 2010). $\mathrm{Na}$ and $\mathrm{Cl}$ concentrations are substantially higher than in the perched aquifers (median ca. 420 and $900 \mathrm{mg} \mathrm{Cl} \mathrm{L}^{-1}$ in Malta MSL and Gozo MSL respectively, Table 1), reflecting intrusion of seawater into the fresh water lens, largely in response to intensive abstraction (Sapiano et al., 2006).

\subsection{Nitrate}

\subsubsection{Concentrations and historical trends}

Nitrate concentrations measured in 2008 as part of the present study are presented in Table 1 and summarised in Figure 2. All three aquifers display similar values for their lowest nitrate concentrations: about 6 to $10 \mathrm{mg} \mathrm{NO}_{3}-\mathrm{N} \mathrm{L}^{-1}$. These levels are well above those typically thought to represent background concentrations in Europe (less than $2 \mathrm{mg} \mathrm{NO} \mathrm{N}_{3} \mathrm{~N} \mathrm{~L}^{-1}$, EEA (1999)), and suggest that there may be no part of Malta where the groundwater is unaffected by human activity. The perched aquifers display the largest range of concentrations, to almost $100 \mathrm{mg} \mathrm{NO}_{3}-\mathrm{N} \mathrm{L}^{-1}$, and the highest median value (ca. $37 \mathrm{mg} \mathrm{NO}_{3}-\mathrm{N} \mathrm{L}^{-1}$ ). Values are lower in the Malta MSL (median ca. 14 $\mathrm{mg} \mathrm{NO}_{3}-\mathrm{N} \mathrm{L}^{-1}$ ), and lowest in the Gozo MSL (median ca. $10 \mathrm{mg} \mathrm{NO}_{3}-\mathrm{N} \mathrm{L}^{-1}$ ), though even here more than one third of the samples exceed the EU limits for drinking water.

The earliest analyses of groundwater suggest nitrate levels were very low in the $1860 \mathrm{~s}$, but had risen substantially by the 1960s (BRGM, 1991). Comparing the 2008 analyses in Table 1 with data for the same water sources in 1991 (BRGM, 1991) reveals that the nitrate concentrations in the perched aquifers are continuing to rise - a median increase of $11 \mathrm{mg} \mathrm{NO}_{3}-\mathrm{N} \mathrm{L}^{-1}(\mathrm{n}=9$ sources) over the past 17 years. In contrast, there was no evidence for significant overall changes in the MSL 
aquifers over this period (median changes $<1 \mathrm{mg} \mathrm{NO}_{3}-\mathrm{N} \mathrm{L}^{-1}$ in Malta $(\mathrm{n}=18$ sources) and Gozo ( $\mathrm{n}$ =13) MSL aquifers).

\subsubsection{Potential nitrogen inputs}

About half of Malta's land area is taken up by intensive agriculture, which is recognised as a possible source of nitrate pollution (BRGM, 1991; Meli, 1993; Mangion, 2001). Potatoes and other vegetables constitute the major crops, but much of the cultivated area goes towards growing forage for livestock (NSO, 2008). With limited land available, this livestock production is intensive, with cattle, pigs, poultry and rabbits kept in stockyards or cages most of the time (Meli, 1993). A recent estimate of nitrogen balances (NSO, 2008) suggests that the arable production is supported by addition of an estimated $60 \mathrm{~kg} \mathrm{~N} \mathrm{ha}^{-1} \mathrm{a}^{-1}$ applied as mineral fertilizer, and an additional 95 million $\mathrm{kg} \mathrm{N} \mathrm{ha}{ }^{-1} \mathrm{a}^{-1}$ applied as animal manure fertiliser, usually in the late summer. This manure fertiliser, however, is mainly the solid animal waste, and only constitutes about $60 \%$ of the total production of animal waste nitrogen. The remainder, chiefly pig slurry, being disposed as sewage (NSO, 2008).

Disposal of animal and human sewage is by networks of mains sewers draining the densely populated parts of the islands, and septic tanks and cesspits serving smaller or more isolated communities. Indequacies in capacity or the sealing of these systems against leakage may also have constituted a source of nitrate pollution (Mangion, 2001; Sapiano et al., 2006).

Mineral fertilizers, animal and human sewage waste, and soil cultivation must therefore all be regarded as potential sources of nitrate. Atmospheric deposition, which might provide high concentrations of nitrate under certain conditions of intense evaporation in very arid environments, is not considered a significant source.

\section{Methods}

\subsection{Groundwater collection and chemical analysis}

In January and March, 2008, fifty groundwater samples were collected from the mean sea level (MSL) aquifers on Malta and Gozo, and from some of the perched aquifers on Malta (Figure 3, Table 1). Sample locations were selected to represent the different landuse types (agricultural and urban areas) and proximity to potential point sources of pollution (sewer galleries, livestock enclosures). The landuse classifications (Table 1) were based on specific activities known to occur within 100-metre radius of the sampling site, rather than all landuse in the immediate vicinity. Given the complex patchwork nature of landholding and activities on Malta, and the fact that boreholes and galleries tap groundwater derived from a wide area, the landuse classifications shown in Table 1 must be regarded as somewhat arbitrary: in many cases a 'mixed' classification may be more appropriate. Boreholes and pumping stations were well flushed (if not already in operation), with chlorine disinfection turned off, and samples for analysis (all $0.45 \mu \mathrm{m}$ filtered) taken only when temperature, conductivity, $\mathrm{pH}$ and dissolved oxygen had stabilised. Water alkalinity and dissolved oxygen were measured at the sampling site by titration and membrane electrode, respectively.

Filtered samples for nitrate isotope analysis were passed through cation and anion resins within 48 hours of collection, with the amount of sample to yield sufficient nitrate without overloading the resins being based on measurement of nitrate concentration (Hach DR/890 colorimeter) and estimated chloride concentration (from known chloride versus conductivity relationship (BRGM, 1991)). Filtered samples for chemical analysis by plasma optical emission spectrometry were acidified with nitric acid; filtered samples for nitrogen species analysis by segmented flow colorimetry, and for $\mathrm{H}_{2} \mathrm{O}$ isotope analysis were untreated. 


\subsection{Sewage and animal wastes, fertilizers, and soils}

Sewage was collected from communal cesspits, and from the piped network draining industrial and residential areas upstream of sewage treatment. Animal wastes were collected from clamps and pits in cattle, pig and poultry units. Samples were refrigerated, and liquid samples acidified to $\mathrm{pH} 3$ to 4 within 4 days of collection.

Samples of synthetic fertilizers, representing commonly used products from four different manufacturers, were provided as dry powder by an agricultural cooperative.

Composite topsoil samples were supplied as dry, archived material from the Agricultural Services Division.

\subsection{Preparation for isotope analysis}

Anion resins containing nitrate were eluted with hydrobromic acid, and processed to silver nitrate (Chang et al., 1999; Heaton et al., 2004).

Solid animal wastes were slurried with water on a shaker table and centrifuged, with the resulting supernatants and the liquid wastes filtered to $<2 \mu \mathrm{m}$. Following $\mathrm{HACH}$ colorimetric analysis of ammonium concentrations, sufficient solution to contain about $1 \mathrm{mg} \mathrm{NH}_{4}-\mathrm{N}$ was converted to ammonium sulphate on a quartz filter paper using an alkaline diffusion method (Heaton, 2001).

Solid fertilizers were dissolved in water and filtered to $<0.45 \mu \mathrm{m}$. Ammonium was determined and converted to ammonium sulphate using the same method as for animal waste ammonium. Nitrate concentration was determined by $\mathrm{HACH}$ colorimetric analysis and converted to silver nitrate using the same method as for groundwater nitrate.

Soils were reacted with $5 \%$ hydrochloric acid for 20 hours to remove carbonate, rinsed free of chloride with de-ionised water, dried at $50^{\circ} \mathrm{C}$, ground to a powder, and homogenised. Weight $\% \mathrm{C}$ and weight $\% \mathrm{~N}$ were determined by Elemental Analyser against an acetanilide standard.

\subsection{Isotope analysis}

${ }^{15} \mathrm{~N} /{ }^{14} \mathrm{~N}$ ratios of silver nitrate, soils, or ammonium sulphate filters were analysed by combustion in a Flash EA on-line to a Delta Plus XL mass spectrometer (ThermoFinnigan, Bremen, Germany). Isotope ratios were calculated as $\delta^{15} \mathrm{~N}$ values versus air (atmospheric $\mathrm{N}_{2}$ ) by comparison with standards calibrated against IAEA N-1 and N-2 assuming these had values of $+0.4 \%$ and $+20.3 \%$, respectively. Analytical precision (1 SD) was typically $<0.3 \%$.

${ }^{18} \mathrm{O} /{ }^{16} \mathrm{O}$ ratios of silver nitrate were analysed by thermal conversion to $\mathrm{CO}$ gas at $1400^{\circ} \mathrm{C}$ in a TC-EA on-line to a Delta Plus XL mass spectrometer (ThermoFinnigan, Bremen, Germany). Isotope ratios were calculated as $\delta^{18} \mathrm{O}$ values versus SMOW by comparison with IAEA-NO3 assuming it had a value of $+25.6 \%$. Analytical precision ( $1 \mathrm{SD}$ ) was typically $<0.6 \%$.

Water ${ }^{2} \mathrm{H} /{ }^{1} \mathrm{H}$ ratios were analysed by conversion to $\mathrm{H}_{2}$ gas in a chromium furnace (Eurovector, Milan, Italy) on-line to an Isoprime mass spectrometer (GV Instruments, Manchester, England), and ${ }^{18} \mathrm{O} /{ }^{16} \mathrm{O}$ ratios by equilibration with $\mathrm{CO}_{2}$ in an Isoprep 18 coupled to a SIRA dual-inlet mass spectrometer (VG Instruments, Middlewich, England). $\delta^{2} \mathrm{H}$ and $\delta^{18} \mathrm{O}$ values versus VSMOW were determined by comparison with laboratory standard waters calibrated against VSMOW and SLAP. Analytical precision ( $1 \mathrm{SD}$ ) was typically $<1 \%$ for $\delta^{2} \mathrm{H}$ and $<0.03 \%$ for $\delta^{18} \mathrm{O}$.

\section{Results}

The ${ }^{15} \mathrm{~N} /{ }^{14} \mathrm{~N}$ and ${ }^{18} \mathrm{O} /{ }^{16} \mathrm{O}$ analyses of groundwater nitrate are shown in Table 2 and Figure 4. It is noteable that, with the exception of two samples, all three aquifer types - the perched and MSL aquifers on Malta, and the MSL aquifer on Gozo - have groundwater displaying very similar ranges of $\delta^{15} \mathrm{~N}$ and $\delta^{18} \mathrm{O}$ values: $\delta^{15} \mathrm{~N}$ between +7.2 to $+13.2 \%$, and $\delta^{18} \mathrm{O}$ between +2.8 to $+6.4 \%$. Within these ranges there was no apparent relationship between isotope composition and the land use 
classification in Table 1 (but see Table 1 footnote for the limitations of this classification). The two exceptions to the typical range are GW 282 and GW 283, which have $\delta^{15} \mathrm{~N}$ and $\delta^{18} \mathrm{O}$ values elevated above the typical values in the proportion approximately 2 to $1-$ i.e. producing samples falling on a line with a $\delta^{18} \mathrm{O} / \delta^{15} \mathrm{~N}$ slope of 0.5 in Figure 4. This is a feature generally indicative of the effects of partial denitrification (Kendall et al., 2007; Singleton et al., 2007).

$\delta^{15} \mathrm{~N}$ and $\delta^{18} \mathrm{O}$ values for synthetic inorganic fertilizers utilised in Malta are shown in Table 3. $\delta^{15} \mathrm{~N}$ values conform to the usual pattern of slightly lower values for ammonium $(-5.0$ to $+0.3 \%$ o than for nitrate $(+1.3$ to $+3.5 \%)$, but all types are within the typical ranges reported for fertilizers in other countries (Vitòria et al., 2004; Bateman and Kelly, 2007). The $\delta^{18} \mathrm{O}$ values for the fertilizer nitrate, +24 to $+26 \%$, reflect its derivation from atmospheric $\mathrm{O}_{2}\left(\delta^{18} \mathrm{O}=+23.5 \%\right.$; Kroopnick and Craig, 1972) are also similar to other published values (Vitòria et al., 2004).

Nitrate concentrations in sewage were consistently very low (Table 4), and no nitrate was detectable by colorimetric test kit in the animal waste samples. All of these materials, however, had high concentrations of ammonium (Table 4). Because liquid animal wastes are known to be discharged into sewers, they are included with actual sewage samples to suggest that the entire range of $\delta^{15} \mathrm{~N}$ values for sewer ammonium is quite narrow: +3.1 to $+6.9 \%$. Similar values, in the range +4.3 to $+7.0 \%$, have been reported for ammonium and total $\mathrm{N}$ in sewage effluent in other countries (Liu et al., 2006; Shomar et al., 2008). In contrast, the solid animal wastes from Malta which are stored and spread on the land, and are here regarded as manure, displayed a much broader range of values: +2.1 to $+10.1 \%$.

Data for 17 samples of soil, representative of the main soil types from both islands, are shown in Table 5. The range of $\delta^{15} \mathrm{~N}$ values for organic nitrogen in cultivated soils, +6.0 to $+11.2 \%$, was wide, with many of the higher values being at the upper end of the range typically reported for soils (Kendall et al., 2007). Three samples of uncultivaed soil, however, had generally lower $\delta^{15} \mathrm{~N}$ values (+3.9 to $+7.2 \%$, Table 5$)$.

\section{Discussion}

With the exception of some of the fertilizers, the potential sources of nitrate analysed in this study are in the form of ammonium or organic nitrogen. We therefore consider the probable $\delta^{15} \mathrm{~N}$ and $\delta^{18} \mathrm{O}$ values of nitrate which might be expected to form from mineralisation and nitrification of these sources on theoretical grounds. The values are compared with those of the groundwater in Figure 5.

\subsection{Principles governing $\delta^{15} \mathrm{~N}$ values of potential sources of nitrate}

Mineralisation (ammonification) of organic nitrogen to form ammonium is normally accompanied by only a small isotope fractionation, so that the $\delta^{15} \mathrm{~N}$ value of the ammonium is similar to that of the organic N (Kendall et al., 2007). Several factors, however, may influence the $\delta^{15} \mathrm{~N}$ values of nitrate formed by nitrification of ammonium (Mariotti et al., 1981; Heaton, 1986; Heaton et al., 2005; Böhlke, 2002; Kendall et al., 2007):

a) If the ammonium is completely nitrified, the total nitrate will have a $\delta^{15} \mathrm{~N}$ value equal to that of the initial ammonium (a requirement of isotope mass balance);

b) If the ammonium is only partially nitrified, isotope fractionation can lead to production of nitrate with a $\delta^{15} \mathrm{~N}$ value lower than that of the initial ammonium; 
c) Where high concentrations of ammonium are present under alkaline conditions, volatilisation losses of ${ }^{15} \mathrm{~N}$-depleted gaseous ammonia can lead to ${ }^{15} \mathrm{~N}$-enrichment of the residual ammonium which, on oxidation, can form nitrate with high $\delta^{15} \mathrm{~N}$ values;

d) Nitrate with high $\delta^{15} \mathrm{~N}$ values can also be formed under anoxic conditions by partial denitrification in which loss of ${ }^{15} \mathrm{~N}$-depleted $\mathrm{N}_{2}$ leaves residual nitrate with a high $\delta^{15} \mathrm{~N}$ value. However, partial denitrification not only results in an increase in the $\delta^{15} \mathrm{~N}$ values of the remaining nitrate, but also an increase in its $\delta^{18} \mathrm{O}$ value. The proportions are about 2 to 1 , respectively (Böttcher et al., 1990; Singleton et al., 2007). As a result, if a source of nitrate undergoes different degrees of denitrification, samples plotted on a graph of $\delta^{18} \mathrm{O}$ versus $\delta^{15} \mathrm{~N}$ will lie on a line with a $\delta^{18} \mathrm{O} / \delta^{15} \mathrm{~N}$ slope of about 0.5 . As noted in section 4, only two groundwater samples show evidence of this (Figure $4 \mathrm{~b}$ ), and the sample with the greatest degree of ${ }^{15} \mathrm{~N}$ - and ${ }^{18} \mathrm{O}$-enrichment (GW 282) also had a particularly low dissolved $\mathrm{O}_{2}$ concentration (Table 1), anoxia being a requirement for denitrification. As none of the other groundwater samples show evidence for denitrification, we do not regard it as having had a significant effect on the isotopic composition of nitrate.

From the above it is clear that there are processes which may lead to the formation of nitrate with $\delta^{15} \mathrm{~N}$ values lower than or the same as those of the source organic $\mathrm{N}$ or ammonium; whereas formation of nitrate with $\delta^{15} \mathrm{~N}$ values higher than the source $\mathrm{N}$ would probably require involvement of ammonia volatilization.

\subsection{Principles governing $\delta^{18} \mathrm{O}$ values of potential sources of nitrate}

With the exception of fertilizer nitrate, whose high $\delta^{18} \mathrm{O}$ value reflects inorganic derivation of oxygen entirely from atmospheric $\mathrm{O}_{2}$, the other sources of nitrate must form by bacterial nitrification. The uncertainties in factors which might determine the $\delta^{18} \mathrm{O}$ value of bacterial nitrate have been summarised elsewhere (Kendall et al., 2007; Spoelstra et al., 2007). In the simplest case, however, autotrophic nitrification is typically thought to derive two oxygen atoms from water, and one from atmospheric $\mathrm{O}_{2}$, with the expected $\delta^{18} \mathrm{O}$ value of nitrate being:

$\delta^{18} \mathrm{O}_{\mathrm{NO} 3}=2 / 3 \cdot \delta^{18} \mathrm{O}_{\mathrm{H} 2 \mathrm{O}}+1 / 3 \cdot \delta^{18} \mathrm{O}_{\mathrm{O} 2} \quad$ Eqn. 1

Atmospheric $\mathrm{O}_{2}$ has $\delta^{18} \mathrm{O}=+23.5 \%$ (Kroopnick and Craig, 1972).

In Bakalowicz and Mangion's (2003) study of Maltese waters, over $80 \%$ of the rainwater samples had $\delta^{18} \mathrm{O}$ values within the -5.3 to $-4.3 \%$ range we find for groundwater (Table 2 ). We therefore use this range for the expected $\delta^{18} \mathrm{O}$ value for water involved in nitrification of fertilizer ammonium, manure or soil $\mathrm{N}$ in natural near-surface environments. The expected $\delta^{18} \mathrm{O}$ values for nitrate from equation 1 would then be +4.3 to $+5.0 \%$. Bearing in mind the uncertainties and assumptions in the use of this equation, it is interesting that these theoretically-expected values correspond exactly to the middle of the range of values measured for nitrate in the groundwater $\left(\delta^{18} \mathrm{O}=+2.8\right.$ to $+6.4 \%$ ) .

The $\delta^{18} \mathrm{O}$ values of waters in the islands sewage systems, however, are significantly higher than those of groundwater (Table 4); a result of the presence of desalinated seawater in the mains water supply (Stuart et al., 2010). If nitrification of sewage occurred in the presence of water having the same $\delta^{18} \mathrm{O}$ values as the sewage, -2.8 to $-0.4 \%$, then the expected $\delta^{18} \mathrm{O}$ values for sewage nitrate would be +6.0 to $+7.6 \%$. This is somewhat higher than typical values measured for nitrate in the groundwater. 


\subsection{Composition of potential sources}

\subsubsection{Fertilizer}

In the absence of ammonia volatilisation, total or partial nitrification of fertilizer ammonium with $\delta^{15} \mathrm{~N}=-5.0$ to $+0.3 \%$ (Table 3) would lead to formation of nitrate with similar or lower $\delta^{15} \mathrm{~N}$ values; in other words $\delta^{15} \mathrm{~N}$ values not higher than $+0.3 \%$. Under certain conditions, however, ammonia volatilisation is believed to be a possible cause of elevated $\delta^{15} \mathrm{~N}$ values where high concentrations of ammonium fertilizers are applied (Nommik et al., 1994; Hogberg, 1997). We cannot discount this possibility for the moderately alkaline soils of Malta (pH 7.3 to 8.5, MEPA (2006)), but doubt that it would increase $\delta^{15} \mathrm{~N}$ values by more than a few per mil. We therefore assume that nitrate derived directly from fertilizer is unlikely to have a value higher than about $+4 \%$, which is considerably lower than the values for groundwater (Figure 5a).

The $\delta^{18} \mathrm{O}$ data also rule out direct derivation from fertilizer. We do not know the proportions in which nitrate-based versus other forms of fertilizers are used in Malta. But as it is inconceivable that nitrate derived from nitrification of fertilizer ammonium might be leached down into groundwater without leaching of fertilizer nitrate, even small proportions of fertilizer nitrate would raise $\delta^{18} \mathrm{O}$ to values higher than those found in groundwater (Figure 5a).

\subsubsection{Sewage}

Loss of ammonia by volatilisation is presumably minimal in the below-ground environment. We would therefore not expect nitrate formed in the sewers to have $\delta^{15} \mathrm{~N}$ values above the highest measured value for sewage ammonium, $+6.9 \%$. Anisfield et al. (2007) also noted $\delta^{15} \mathrm{~N}$ values $\leq$ $+7 \%$ for nitrate in sewage which had undergone little gas loss. These values are lower than those for nitrate in the groundwater. As noted above, moroever, the expected $\delta^{18} \mathrm{O}$ values for sewagederived nitrate are also slightly different from those measured in groundwater (Figure 5a).

\subsubsection{Manure}

Compared with sewage, it is much more difficult to put limits on the likely $\delta^{15} \mathrm{~N}$ values for nitrate derived from manure - the solid animal waste stored and spread on the land. In the subaerial environment, and especially under alkaline conditions of composting in clamps, ammonia volatilisation is known to result in high $\delta^{15} \mathrm{~N}$ values (Heaton, 1986; Kendall et al., 2007; Kim et al., 2008). The magnitude of this ${ }^{15} \mathrm{~N}$-enrichment will be dependent on the nature of the starting material, storage conditions and degree of decomposition, and variations in these factors probably account for the wide range of $\delta^{15} \mathrm{~N}$ values measured for ammonium in manure $(+2.1$ to $+10.1 \%$, Table 4). In addition, the manures in Table 4 were collected in March, when they were relatively 'fresh', whereas the main period of manure spreading tends to be in the autumn. Therefore, whilst the maximum measured $\delta^{15} \mathrm{~N}$ value in Table 4 was $+10.1 \%$, we cannot discount the possibility that manures applied to the land after a longer period of composting would have ammonium, and hence nitrate with $\delta^{15} \mathrm{~N}$ values higher than $+10.1 \%$. A great many studies have demonstrated that nitrate derived from animal wastes commonly has $\delta^{15} \mathrm{~N}$ values between +8 to $+20 \%$ (Fogg, 1998).

In the absence of any published data for the $\delta^{18} \mathrm{O}$ values of nitrate formed from solid animal waste, Figure $5 \mathrm{a}$ uses values of +4.3 to $+5.0 \%$ on the basis of assuming that $\delta^{18} \mathrm{O}_{\mathrm{H} 2 \mathrm{O}}$ and $\delta^{18} \mathrm{O}_{\mathrm{O} 2}$ in Equation 1 are the same as those for groundwater and atmospheric $\mathrm{O}_{2}$ respectively (section 5.2.). In the composting of manure, however, the production and evaporation of water, and the consumption of oxygen might provide circumstances producing very different $\delta^{18} \mathrm{O}$ values (Kendall et al., 2007).

\subsubsection{Soils}

From studies of global relationships between soil $\delta^{15} \mathrm{~N}$ values and climate the uncultivated soils on Malta might be expected to have $\delta^{15} \mathrm{~N}$ values of about +4 to $+6 \%$ (Handley et al., 1999; 
Amundson et al., 2003). Natural soils are rare on Malta, but the three samples noted as 'uncultivated or abandoned' in Table 5 have values $(+3.9$ to $+7.2 \%$ ) which are not inconsistent with this. In contrast, cultivated soils on Malta have much higher values $(+6.0$ to $+11.2 \%$ ) averaging $+9.1 \%$. Soil $\mathrm{N}$ models suggest that these high $\delta^{15} \mathrm{~N}$ values may reflect conditions of greater 'openness' to nitrogen, favouring losses of ${ }^{15} \mathrm{~N}$-depleted nitrogen and accumulation of residual, more stable forms of organic nitrogen with higher $\delta^{15} \mathrm{~N}$ values (Handley et al., 1999; Conen et al., 2008). These circumstances may be promoted by prolonged cultivation (Broadbent et al., 1980; Aranibar et al., 2008 ), with the possibility that high soil $\delta^{15} \mathrm{~N}$ values are indicative of excess $\mathrm{N}$ fertilisation (Kriszan et al., 2009).

The relationship between the $\delta^{15} \mathrm{~N}$ values of soil total $\mathrm{N}$ and of soil nitrate is complicated, with short-term incubation and lysimeter studies revealing both positive and negative

$\delta^{15} \mathrm{~N}_{\mathrm{NO} 3}-\delta^{15} \mathrm{~N}_{\text {soil }}$ differences varying both with time (season) and depth in the soil profile (Ostrom et al., 1998; Handley et al., 2001; Burns and Kendall, 2002). In addition, there have been few detailed studies comparing the $\delta^{15} \mathrm{~N}$ values of both soil $\mathrm{N}$ and groundwater nitrate in areas where the soil is the only source of nitrate. For the purpose of the present investigation we will assume that, over the longer term, the average $\delta^{15} \mathrm{~N}$ value of soil-derived nitrate recharging to groundwater will be similar to the $\delta^{15} \mathrm{~N}$ value of soil $\mathrm{N}$. In this case nitrate derived from cultivated soils on Malta would have $\delta^{15} \mathrm{~N}$ values between +6.0 to $+11.2 \%$ and, on the assumptions above (section 5.2.), $\delta^{18} \mathrm{O}$ values of +4.3 to $+5.0 \%$ (Figure $5 \mathrm{~b}$ ).

\subsection{Sources of groundwater nitrate}

$\delta^{15} \mathrm{~N}$ values for nitrate in the non-denitrified groundwaters fall within a fairly narrow range; $90 \%$ of samples lying within a $4 \%$ interval $(+7.7$ to $+11.7 \%$, Table 2$)$. There are no apparent relationships with local landuse (see footnote to Table 1), or water chemistry, and also no apparent relationships with sample location. Some of this uniformity in $\delta^{15} \mathrm{~N}$ values, and lack of relationship with landuse could reflect the long travel times and opportunity for mixing in the MSL aquifers. But this would not account for the uniformity in the Malta perched aquifer, or the very close similarity between all three aquifer types, for which mean $\delta^{15} \mathrm{~N}$ values are essentially identical $(+9.5 \%$, $+9.8 \%$, and $+9.8 \%$ in the Malta perched, Malta MSL, and Gozo MSL aquifers respectively). Barring coincidence, therefore, we suggest that the nitrate source/s are everywhere similar, with the slight variations in $\delta^{15} \mathrm{~N}$ reflecting slight temporal or spatial variations in the isotopic composition of the nitrate source/s. The marked difference between the nitrate concentrations in the three aquifers is believed to reflect hydrological differences: waters in the perched aquifers being recently recharged, with older water in the Malta MSL, and older still in the Gozo MSL (Stuart et al. 2010).

$\delta^{18} \mathrm{O}$ values for nitrate in the non-denitrified groundwaters also fall within a narrow range ( $90 \%$ of samples within a $3 \%$ interval, Table 2 ), with no relationship to landuse, chemistry or location. Within our limits of knowledge about the isotope aspects of nitrification, the $\delta^{18} \mathrm{O}$ values correspond exactly to what would be expected for microbial nitrification in the presence of surface or groundwaters.

The isotope composition of groundwater nitrate is compared with the composition of potential sources in Figure 5. The data rule out nitrate derived by direct leaching of fertilizers, and nitrate from human or liquid animal wastes in the sewage system. The data are compatible with nitrate being derived from manure (solid animal waste) or from the soil.

In many nitrate isotope studies, the c. +8 to $+12 \% o \delta^{15} \mathrm{~N}$ values typical of Maltese groundwater would be regarded as indicating at least some contribution from sewage or manure sources (Heaton, 1986; Kendall et al., 2007). This partly reflects the fact that under certain conditions these sources are known to be capable of producing high concentrations of nitrate with elevated $\delta^{15} \mathrm{~N}$ values. In addition, it is also a fact that soils are often not measured as part of nitrate 
isotope studies, and it is generally assumed that soil $\delta^{15} \mathrm{~N}$ values are rarely above $+10 \%$. With the cultivated Maltese soils having $\delta^{15} \mathrm{~N}$ values in the range +6 to $+11 \%$, very similar to the values for nitrate in the groundwater, nitrification of soil $\mathrm{N}$ becomes a definite candidate as the major source of nitrate.

Identifying soil $\mathrm{N}$ as the source of nitrate says nothing about the original source of the soil $\mathrm{N}$ itself. Agriculture in Malta has a long history (Busuttil, 1993), and it may be that the manure or fertilizer added to maintain soil fertility over this time constitutes the original source of soil N. But when it is assimilated into the soil $\mathrm{N}$ pool, the isotopic identity of an initial manure or fertilizer source of $\mathrm{N}$ becomes lost. Subsequent mineralisation, nitrification, and loss of the soil $\mathrm{N}$ as nitrate leached into the underlying groundwater, implies that there are periods of $\mathrm{N}$ saturation (even if only temporary, e.g. during the rainy season). It is possible that such saturation partly results from the nature of Maltese soils, which have generally low soil organic carbon contents (half of soils having $<2 \% \mathrm{C}$; MEPA, 2005). Measurements of a few soils suggest that $\mathrm{C} / \mathrm{N}$ ratios are low (about 10 ; Table 5), a factor which may favour higher amounts of $\mathrm{N}$ mineralisation (Springob and Kirchmann, 2003).

\section{Summary and conclusions}

Fertilizers, manure, sewage systems, and soil cultivation are regarded as the main potential sources of high nitrate concentrations in Maltese groundwater. With water chemistry influenced by saline intrusions, however, and a very mixed pattern of human activity scattered over islands of limited land area, it has proved difficult to identify possible nitrate sources by using chemical tracers or examining spatial relationships to specific activities (Stuart et al., 2010). Hence the focus on an isotope study.

Evidence for denitrification was found in only two groundwater samples, implying that this process has not had a substantial effect on nitrate concentrations or isotope compositions. The overall range of concentrations varied widely - more than an order of magnitude - but there was no relationship with isotope composition, which had a very restricted range. In view of the marked hydrological differences between the perched and Malta MSL aquifers, and the physical separation of the Malta MSL and Gozo MSL, this uniformity of isotope composition suggests that the same type of nitrate source is present in all cases.

The relatively high $\delta^{15} \mathrm{~N}$ values of the groundwater nitrate (typically +8 to $+12 \%$ ) suggest that fertilizers and sewage systems are not the sources. The $\delta^{18} \mathrm{O}$ values, which are very similar to the values expected for bacterial nitrification in the presence of local natural waters, also tend to rule out these sources. The data do not rule out the possibility that the nitrate is derived from manure which has undergone ${ }^{15} \mathrm{~N}$-enrichment by processes such as ammonia volatilisation during storage. But given the wide variation to be expected for these storage conditions, and the corresponding variations to be expected for the $\delta^{15} \mathrm{~N}$ values of manure-derived nitrate from the many hundreds of individual clamps scattered over the islands, it is difficult to see how these sources would lead to such a consistent and narrow range of $\delta^{15} \mathrm{~N}$ values for nitrate in the groundwater.

This study emphasised the importance of measuring, rather than assuming the $\delta^{15} \mathrm{~N}$ values of soils. Values for the Maltese soils are quite high, possibly as a result of a long history of cultivation. The isotope data are entirely consistent with nitrification of organic matter in the soils being the major source of nitrate in Malta's groundwater. Given the long period of cultivation it seems likely that this soil organic $\mathrm{N}$ was ultimately derived from fertilizer or manure. If the soil source is correct, then it implies a system in which fertilizer or manure $\mathrm{N}$ is assimilated into the soil organic pool, and that $\mathrm{N}$ from this pool is then mineralised to nitrate and leached from the soil. The nitrate 
concentrations in this leachate are clearly high, and would imply a possible seasonally-influenced process in which nitrate is produced at a time when it is in excess of crop requirements.

A remaining question concerns the historic timing of this nitrate pollution. The fact that the youngest waters - those of the shallow perched aquifers - have the highest nitrate concentrations, and that these concentrations are increasing, argues for an increase in nitrate release from the soils above the perched aquifers in the past few decades. If similar processes have occurred above the MSL aquifers, where infiltrating waters have a longer residence time in the thicker unsaturated zones, will their nitrate concentrations also increase in the future when infiltrating waters finally reach the MSL water table?

\section{Acknowledgements}

The authors are grateful to the technical staff of the Water Services Corporation and the Ministry for Rural Affairs and the Environment, Agricultural Services and Rural Development for assistance and facilitation of sample collection, to the Agricultural Cooperative for fertilizer samples, and to private site owners for access for groundwater sampling. The authors would like to thank colleagues in NIGL, in particular to Carol Arrowsmith, and at BGS Wallingford, John Chilton, Louise Maurice, Peter Williams, Chris Milne and Debbie Allen for their contribution. The project was funded by Technical Assistance Programme under the Rural Development Programme for Malta 2004-2006. This paper is published by permission of the Executive Director of the British Geological Survey. 


\section{REFERENCES}

Amundson, R., Austin, A.T., Schuur, E.A.G., Yoo, K., Matzek, V., Kendall, C., Uebersax, A., Brenner, D. and Baisden, W.T. (2003). Global patterns of the isotopic composition of soil and plant nitrogen. Global Biogeochemical Cycles, 17, article no. 1031.

Anisfield, S.C., Barnes, R.T., Altabet, M.A. and Wu, T. (2007) Isotopic apportionment of atmospheric and sewage nitrogen sources in two Connecticut rivers. Environmental Science and Technology, 41, 6363-6369.

Aranibar, J.N., Anderson, I.C., Epstein, H.E., Feral, C.J.W., Swap, R.J., Ramontsho, J. and Macko, S.A. (2008) Nitrogen isotope composition of soils, $\mathrm{C}_{3}$ and $\mathrm{C}_{4}$ plants along land use gradients in southern Africa, Journal of Arid Environments, 72, 326-337.

Bakalowicz, M. and Mangion, J., 2003. The limestone aquifers of Malta; their recharge conditions from isotope and chemical surveys, Hydrology of the Mediterranean and Semiarid Regions. Proceedings of an International Symposium. IAHS, Montpelier, pp. 49-54.

Böhlke, J.K. (2002) Groundwater recharge and agricultural contamination. Hydrogeology Journal, 10, 153-179.

Böttcher J, Strebel O, Voerkelius S and Schmidt HL (1990) Using isotope fractionation of nitratenitrogen and nitrate-oxygen for evaluation of microbial denitrification in a sand y aquifer. Journal of Hydrology: 114, 413-424.

BRGM (1991) Study of the fresh-water resources of Malta. Bureau de Recherche Geologique et Miniere, France

Broadbent, F.E., Rauschkolb, R.S., Lewis, K.A. and Chang, G.Y., 1980. Spatial variability in nitrogen-15 and total nitrogen in some virgin and cultivated soils. Society of America Journal 44, 524-527.

Burns, D.A. and Kendall, C. (2002). Analysis of $\delta^{15} \mathrm{~N}$ and $\delta^{18} \mathrm{O}$ to differentiate $\mathrm{NO}_{3}{ }^{-}$sources in runoff at two watersheds in the Catskill Mountains of New York. Water Resources Research, 38 , art. no. 1051.

Busuttil, S. (1993) Agriculture in Malta: a historical note. Options Méditerranéennes, Series B, no. 7, 9-26.

Conen, E., Zimmermann, M., Leifeld, J., Seth, B. and Alewell, C. (2008) Relative stability of soil carbon revealed by shifts in $\delta^{15} \mathrm{~N}$ and C:N ratio. Biogeosciences, 5, 123-128.

DOIM, 2009. Department of Information, Malta. http://www.gov.mt

EC, 1991 Council Directive of 12 December 1991 concerning the protection of waters against pollution caused by nitrates from agricultural sources. (91/676/EEC)

EEA, 1999. Groundwater quality and quantity in Europe. Environmental Assessment Report no .3. European Environment Agency, Copenhagen.

EEA, 2008. Present concentration of nitrate in groundwater bodies in European countries, 2005. European Environment Agency $\mathrm{http}: / /$ dataservice.eea.europa.eu/atlas/viewdata/viewpub.asp? $\mathrm{id}=3423$

EU, 2000 Directive of the European Parliament and of the Council of 23 October 2000 establishing a framework for the Community action in the field of water policy (2000/60/EC)

Fogg, G.E.; Rolston, D.E.; Decker, D.L., Louie, D.T. and Grismer, M.E. (1998) Spatial variation in nitrogen isotope values beneath nitrate contamination sources. Groundwater, 36, 418-426.

Handley, L.L., Austin, A.T., Robinson, D., Scrimgeour, C.M., Raven, J.A., Heaton, T.H.E., Schmidt, S. and Stewart, G.R. (1999). The ${ }^{15} \mathrm{~N}$ natural abundance $\left(\delta^{15} \mathrm{~N}\right)$ of ecosystem samples reflects measures of water availability. Australian Journal of Plant Physiology, 26, 185-199. 
Handley, L.L., Johnston, A.M., Hallett, P.D., Scrimgeour, C.M. and Wheatley, R.E. 2001. Development of $\delta^{15} \mathrm{~N}$ stratification of $\mathrm{NO}_{3}{ }^{-}$in soil profiles. Rapid Communications in Mass Spectrometry, 15, 1274-1278.

Heaton, T.H.E. (1986). Isotopic studies of nitrogen pollution in the hydrosphere and atmosphere: a review. Chemical Geology, 59, 87-102.

Heaton, T.H.E. (2001). Procedure and notes on the 'diffusion' method for ${ }^{15} \mathrm{~N} /{ }^{14} \mathrm{~N}$ analysis of nitrate and ammonium. NERC Isotope Geoscience Laboratory, report NIGL 176, $5 \mathrm{pp}$.

Heaton, T.H.E., Trick, J.K. and Williams, G.M. (2005). Isotope and dissolved gas evidence for nitrogen attenuation in landfill leachate dispersing into a chalk aquifer. Applied Geochemistry, 20, 933-945.

Högberg, P. (1997). Tansley review no. 95: ${ }^{15} \mathrm{~N}$ natural abundance in soil-plant systems. New Phytologist, 137, 179-203.

Kendall, C. (1998) Tracing nitrogen sources and cycling in catchments. In C. Kendall and J.J. McDonnell (Eds.), Isotope Tracers in Catchment Hydrology. Elsevier Science B.V. (Amsterdam), pp. 519-576.

Kendall, C., Elliott, E.M. and Wankel, S.D. (2007) Tracing anthropogenic inputs of nitrogen to ecosystems. In: R. Michener and K. Lajtha (editors) Stable Isotopes in Ecology and Environmental Science, Blackwell Publishing, 375-449.

Kim, Y.J., Choi, W.J., Lim, S.S, Kwak J.H., Chang S.X., Kim H.Y., Yoon K.S. and Ro, H.M. (2008). Changes in nitrogen isotopic compositions during composting of cattle feedlot manure: effects of bedding material type. Bioresource Technology, 99, 13, 5452-5458.

Kriszan, M., Amelung, W., Schellberg, J., Gebbing, T. and Kühbauch, W. (2009). Long-term changes of the $\delta^{15} \mathrm{~N}$ natural abundance of plants and soil in a temperate grassland. Plant and Soil, 325, 157-169.

Kroopnick, P.M. and Craig, H. (1972). Atmospheric oxygen: Isotopic composition and solubility fractionation. Science, 175, 54-55.

Liu, C.-Q., Li, S.-L., Lang, Y.-C. and Xiao, H.-Y. (2006) Using $\delta^{15} \mathrm{~N}$ and $\delta^{18} \mathrm{O}$ values to identify nitrate sources in karst ground water, Guiyang, Southwest China. Environmental Science and Technology, 40, 6928-6933.

Mangion, J. (2001) The demand for water by the agricultural sector in Malta. Proceedings APS Seminar 2001: Water and Agriculture in a Competitive Environment. APS Bank, Malta, p. 4256. http://www.apsbank.com.mt/filebank/documents/APSproceed01.pdf

Mangion, J., Micallef, P. and Attard, G. (2005) Treated sewage effluent - an alternative water supply for the Maltese islands. In A. Hamdy (editor) Non-Conventional Water Use: WASAMED project. Options Méditerranéennes, series B, no. 53, 305-310. ISBN 2-85352-3314

Mariotti, A., Germon, J.C., Hubert, P., Kaiser, P., Letolle, R., Tardieux, A. and Tardieux, P. (1981). Experimental determination of nitrogen kinetic isotope fractionation: some principles; illustration for the denitrification and nitrification processes. Plant and Soil, 62, 413-430.

MEPA (2005). Soil Resources in the Maltese Islands. www.mepa.org.mt/file.aspx? $\mathrm{f}=1821$.

MEPA (2006). State of the Environment report 2005. Malta Environment and Planning Authority, ISBN 99932-83-23-1.

MRAE (2003). The Maltese Code of Good Agricultural Practice. Ministry of Rural Affairs and the Environment, Government of Malta.

Nômmik H, Pluth D J, Larsson K and Mahendrappa M K (1994). Isotopic fractionation accompanying fertilizer nitrogen transformations in soil and trees of a Scots pine ecosystem. Plant and Soil, 158, 169-182.

NSO (2006). Environment Statistics 2006. National Statistics Office, Valetta, Malta. ISBN 97899909-73-40-2. http://www.nso.gov.mt/statdoc/document_file.aspx?id=1969 
NSO (2008). Gross Nitrogen Balance for Malta 2007. National Statistics Office, Valetta, Malta. ISBN 978-99909-73-65-5. http://www.nso.gov.mt/statdoc/document file.aspx?id=2364

Ostrom, N.E, Knoke, K.E., Hedin, L.O., Robertson, G.P. and Smucker, A.J.M. 1998 Temporal trends in nitrogen isotope values of nitrate leaching from an agricultural soil, Chemical Geology, 146, 219-227

Pedley, H.M., House, M.R. and Waugh, B. (1976). The geology of Malta and Gozo. Proceedings of the Geologists Association, 87, 325-341.

Sapiano, M., Mangion, J. and Batchelor, C., 2006. Malta Water Resources Review. Food and Agriculture Organization of the United Nations, Rome, 2006. http://www.fao.org/docrep/009/a0994e/a0994e00.htm.

Shomar, B., Osenbrück, K. and Yahya, A. (2008). Elevated nitrate levels in the groundwater of the Gaza Strip: distribution and sources. Science of the Total Environment, 398, 164-174.

Singleton, M.J., Esser, B.K., Moran, J.E., Hudson, G.B., McNab, W.W. and Harter, T. (2007) Saturated zone denitrification: potential for natural attenuation of nitrate contamination in shallow groundwater under dairy operations. Environmental Science and Technology, 41, 759765.

Springob, G. and Kirchmann, H. (2003). Bulk soil C to N ratio as a simple measure of net $\mathrm{N}$ mineralization from stabilized soil organic matter in sandy arable soils. Soil Biology and Biochemistry, 35, 629-632.

Spoelstra, J., Schiff, S.L., Hazlett, P.W., Jeffries, D.S. and Semkin, R.G. (2007) The isotopic composition of nitrate produced from nitrification in a hardwood forest floor. Geochimica et Cosmochimica Acta, 71, 3757-3771.

Stuart, M.E., Maurice, L., Heaton, T.H.E., Sapiano, M., Micallef Sultana, M., Gooddy, D.C. and Chilton, P.J. (2010) Groundwater residence time and movement in the Maltese islands - A geochemical approach. Applied Geochemistry, 25, 609-620. 
Table 1. Site description and chemical composition of groundwater samples (concentrations in $\mathrm{mg} \mathrm{L}^{-1}$ )

\begin{tabular}{|c|c|c|c|c|c|c|c|c|c|c|c|c|c|}
\hline Sample no. & Land use $^{\mathrm{a}}$ & Type $^{\text {b }}$ & $\mathrm{Na}$ & $\mathrm{K}$ & $\mathrm{Ca}$ & $\mathrm{Mg}$ & $\mathrm{NH}_{4}-\mathrm{N}$ & $\mathrm{HCO}_{3}$ & $\mathrm{Cl}$ & $\mathrm{SO}_{4}$ & $\mathrm{NO}_{3}-\mathrm{N}$ & $\mathrm{NO}_{2}-\mathrm{N}$ & $\mathrm{DO}$ \\
\hline \multicolumn{14}{|c|}{ Perched aquifers } \\
\hline GW 227 & Cesspits & $\mathrm{S}$ & 73.2 & 7.38 & 90 & 12.8 & $<0.02$ & 196 & 144 & 36.3 & 18.20 & 0.0042 & 2.8 \\
\hline GW 234 & Urban & $\mathrm{S}$ & 187 & 35.9 & 126 & 18.9 & $<0.02$ & 191 & 296 & 90 & 41.60 & 0.577 & 5.8 \\
\hline GW 236 & Urban & PS & 109 & 3.26 & 138 & 16 & $<0.02$ & 170 & 212 & 88.3 & 34.30 & 0.0080 & 9.9 \\
\hline GW 237 & Pigs & PS & 102 & 3.11 & 130 & 19.7 & 0.079 & 197 & 227 & 52.1 & 28.40 & 0.0145 & 9.7 \\
\hline GW 241 & Cattle & PS & 212 & 15.7 & 258 & 31.3 & $<0.02$ & 192 & 383 & 264 & 92.70 & 0.0531 & 3.8 \\
\hline GW 242 & Agriculture & $\mathrm{S}$ & 138 & 4.18 & 170 & 21.5 & 0.026 & 139 & 298 & 136 & 46.90 & 0.0027 & \\
\hline GW 256 & None & $\mathrm{S}$ & 52.8 & 1.36 & 81.2 & 8.77 & $<0.02$ & 190 & 94.8 & 25.3 & 9.32 & 0.0025 & \\
\hline GW 257 & Pigs & $\mathrm{S}$ & 122 & 6.55 & 185 & 21.3 & $<0.02$ & 204 & 235 & 126 & 63.90 & 0.0205 & \\
\hline GW 258 & Agriculture & $\mathrm{S}$ & 103 & 2.49 & 107 & 24.2 & $<0.02$ & 144 & 199 & 71.5 & 26.90 & 0.0041 & \\
\hline GW 273 & Agriculture & PS & 223 & 7.8 & 92.6 & 29 & $<0.02$ & 213 & 414 & 57.1 & 9.59 & $<0.001$ & 6.2 \\
\hline GW 284 & Pigs & $\mathrm{S}$ & 148 & 16 & 170 & 20.8 & $<0.02$ & 143 & 287 & 94.3 & 74.30 & 0.0138 & 6.7 \\
\hline GW 285 & Urban & $\mathrm{S}$ & 195 & 43.3 & 116 & 19 & $<0.02$ & 151 & 304 & 69.9 & 39.40 & 0.0028 & 9.4 \\
\hline \multicolumn{14}{|c|}{ Malta MSL aquifer } \\
\hline GW 228 & Pigs & $\mathrm{B}$ & 183 & 25.7 & 106 & 18.7 & $<0.02$ & 181 & 326 & 35.7 & 32.70 & 0.0018 & 9.3 \\
\hline GW 229 & Agriculture & $\mathrm{B}$ & 143 & 7.41 & 93 & 39.1 & $<0.02$ & 271 & 250 & 89.2 & 13.00 & 0.0016 & 8.1 \\
\hline GW 230 & Under perched & B & 139 & 16.9 & 102 & 41.8 & $<0.02$ & 319 & 234 & 111 & 12.00 & $<0.001$ & 6.9 \\
\hline GW 231 & Under perched & B & 187 & 7.45 & 92 & 44.4 & $<0.02$ & 268 & 351 & 84.9 & 9.47 & $<0.001$ & 7.0 \\
\hline GW 232 & Under perched & $\mathrm{B}$ & 239 & 11.2 & 83.8 & 58.1 & $<0.02$ & 297 & 469 & 102 & 8.93 & 0.0014 & 5.1 \\
\hline GW 233 & Agriculture & PS & 191 & 7.92 & 78.4 & 22.4 & 0.074 & 165 & 354 & 50.5 & 8.27 & $<0.001$ & 8.1 \\
\hline GW 238 & Pigs & B & 289 & 14.4 & 116 & 33.1 & 0.211 & 150 & 535 & 64.9 & 22.90 & 0.0374 & 5.4 \\
\hline GW 239 & Cattle & $\mathrm{B}$ & 183 & 8.51 & 103 & 19.4 & $<0.02$ & 141 & 351 & 36.5 & 16.00 & 0.0094 & 8.8 \\
\hline GW 240 & Agriculture & B & 211 & 5.57 & 110 & 17.8 & $<0.02$ & 243 & 396 & 33.4 & 10.10 & 0.0025 & 6.9 \\
\hline GW 243 & Sewers & B & 400 & 10.3 & 132 & 35.5 & $<0.02$ & 222 & 794 & 27.6 & 16.70 & 0.0054 & \\
\hline GW 244 & Agriculture & $\mathrm{B}$ & 119 & 6.72 & 93.3 & 14.3 & $<0.02$ & 208 & 236 & 27.2 & 14.10 & 0.0026 & 8.0 \\
\hline GW 245 & Pigs & $\mathrm{B}$ & 337 & 10.2 & 97.3 & 34 & $<0.02$ & 180 & 667 & 60.8 & 10.60 & 0.0036 & 10.0 \\
\hline GW 246 & Agriculture & B & 571 & 24.5 & 114 & 65.4 & $<0.02$ & 234 & 1230 & 150 & 10.30 & 0.0086 & \\
\hline GW 247 & Cattle & B & 222 & 7.22 & 94.6 & 19.5 & $<0.02$ & 184 & 415 & 42.5 & 11.80 & 0.0037 & 8.6 \\
\hline GW 259 & Urban & $\mathrm{B}$ & 132 & 4.93 & 91.1 & 14.2 & $<0.02$ & 198 & 210 & 41.1 & 15.40 & 0.0179 & 5.3 \\
\hline
\end{tabular}




\begin{tabular}{|c|c|c|c|c|c|c|c|c|c|c|c|c|c|}
\hline GW 260 & Pigs & $\mathrm{B}$ & 130 & 10.5 & 105 & 15.4 & $<0.02$ & 169 & 221 & 32.5 & 31.70 & 0.0076 & 7.4 \\
\hline GW 261 & TSE & $\mathrm{B}$ & 368 & 14.3 & 164 & 44.7 & $<0.02$ & 213 & 677 & 92.3 & 39.10 & 0.0032 & 8.5 \\
\hline GW 262 & Sewers & PS & 329 & 11.3 & 136 & 32.7 & $<0.02$ & 260 & 601 & 84.5 & 21.50 & $<0.001$ & 8.7 \\
\hline GW 263 & Agriculture & $\mathrm{B}$ & 112 & 4.4 & 75.1 & 25.7 & $<0.02$ & 198 & 195 & 30.7 & 10.70 & 0.0012 & 11.7 \\
\hline GW 272 & Urban & $\mathrm{B}$ & 368 & 16.3 & 121 & 43.1 & $<0.02$ & 242 & 713 & 92.4 & 17.40 & 0.0020 & 5.1 \\
\hline GW 274 & Agriculture & PS & 639 & 21.8 & 127 & 66 & $<0.02$ & 214 & 1250 & 113 & 14.00 & 0.0028 & 6.4 \\
\hline GW 281 & TSE & $\mathrm{B}$ & 366 & 11.7 & 130 & 34.2 & 0.066 & 229 & 710 & 84.4 & 24.90 & 0.0081 & 7.6 \\
\hline GW 282 & Sewers & B & 36.7 & 5.26 & 90.5 & 6.44 & $<0.02$ & 279 & 40.1 & 27.1 & $2.26^{\mathrm{c}}$ & 0.0122 & 0.5 \\
\hline GW 283 & Urban & $\mathrm{B}$ & 347 & 21.4 & 142 & 38 & $<0.02$ & 282 & 650 & 102 & $35.70^{c}$ & 0.0074 & 2.9 \\
\hline \multicolumn{14}{|c|}{ Gozo MSL aquifer } \\
\hline GW 248 & Agriculture & $\mathrm{B}$ & 253 & 11.9 & 92.8 & 52.1 & $<0.02$ & 235 & 469 & 91 & 13.60 & 0.0036 & \\
\hline GW 249 & Cattle & $\mathrm{B}$ & 228 & 7.26 & 99.4 & 33.4 & $<0.02$ & 202 & 438 & 43.4 & 15.50 & 0.0014 & \\
\hline GW 250 & Cattle & $\mathrm{B}$ & 1020 & 38.1 & 112 & 135 & $<0.02$ & 210 & 1990 & 221 & 8.99 & 0.0048 & \\
\hline GW 251 & Urban & $\mathrm{B}$ & 470 & 23.7 & 112 & 77.3 & $<0.02$ & & 908 & 141 & 19.70 & 0.0044 & \\
\hline GW 252 & Cattle & $\mathrm{B}$ & 519 & 18.3 & 93.6 & 99.9 & $<0.02$ & 308 & 952 & 196 & 8.58 & 0.0042 & \\
\hline GW 253 & Cattle & $\mathrm{B}$ & 243 & 8.6 & 65.2 & 61.5 & $<0.02$ & 279 & 436 & 68 & 9.86 & 0.0014 & \\
\hline GW 254 & Agriculture & $\mathrm{B}$ & 787 & 42.1 & 132 & 102 & $<0.02$ & 256 & 1490 & 254 & 8.17 & 0.0011 & \\
\hline GW 255 & Pigs & $\mathrm{B}$ & 317 & 10.4 & 85.1 & 84.4 & $<0.02$ & 329 & 526 & 231 & 6.60 & 0.0012 & \\
\hline GW 275 & Cattle & $\mathrm{B}$ & 159 & 4.86 & 95.8 & 18.4 & $<0.02$ & 206 & 323 & 30.5 & 11.80 & 0.0117 & 8.1 \\
\hline GW 276 & Urban & $\mathrm{B}$ & 647 & 25.5 & 114 & 74.4 & $<0.02$ & 160 & 1260 & 116 & 23.60 & 0.0074 & 7.4 \\
\hline GW 277 & Urban & $\mathrm{B}$ & 651 & 20.2 & 123 & 107 & 0.029 & 293 & 1220 & 191 & 10.10 & 0.0046 & 4.8 \\
\hline GW 278 & Agriculture & $\mathrm{B}$ & 540 & 21.4 & 79.5 & 122 & $<0.02$ & 285 & 1010 & 183 & 6.60 & 0.0023 & 2.3 \\
\hline GW 279 & Under perched & $\mathrm{B}$ & 152 & 9.73 & 52.9 & 49.3 & $<0.02$ & 251 & 267 & 68.2 & 5.46 & 0.0021 & 6.6 \\
\hline GW 280 & Urban & $\mathrm{B}$ & 488 & 24.1 & 120 & 81.2 & 0.036 & 266 & 898 & 137 & 19.80 & 0.0067 & 5.8 \\
\hline
\end{tabular}

${ }^{a}$ Main activity within $100 \mathrm{~m}$ of sampling point (NOTE: the small size of landholdings, and diversity of activities, means that in many cases landuse is mixed)

${ }^{\mathrm{b}}$ Type: $\mathrm{B}=$ borehole, $\mathrm{PS}=$ pumping station, $\mathrm{S}=$ spring

${ }^{\mathrm{c}}$ Denitrified 
Table 2 Nitrate concentration and isotope composition of Maltese groundwater

\begin{tabular}{|c|c|c|c|c|c|c|}
\hline Aquifer & Sample no. & $\mathrm{NO}_{3}-\mathrm{N}\left(\mathrm{mg} \mathrm{L}^{-1}\right)$ & $\delta^{15} \mathrm{~N}_{\mathrm{NO} 3}(\% 0)$ & $\delta^{18} \mathrm{O}_{\mathrm{NO} 3}(\%)$ & $\delta^{2} \mathrm{H}_{\mathrm{H} 2 \mathrm{O}}(\% 0)$ & $\delta^{18} \mathrm{O}_{\mathrm{H} 2 \mathrm{O}}(\%)$ \\
\hline \multirow[t]{12}{*}{ Perched } & GW 227 & 18.2 & +9.4 & +3.4 & -28 & -5.3 \\
\hline & GW 234 & 41.6 & +11.2 & +4.9 & -26 & -4.7 \\
\hline & GW 236 & 34.3 & +9.8 & +3.2 & -26 & -4.9 \\
\hline & GW 237 & 28.4 & +8.3 & +3.3 & -25 & -4.8 \\
\hline & GW 241 & 92.7 & +10.7 & +4.7 & -25 & -4.7 \\
\hline & GW 242 & 46.9 & +8.8 & +3.1 & -26 & -5.0 \\
\hline & GW 256 & 9.32 & +8.7 & +4.6 & -29 & -5.5 \\
\hline & GW 257 & 63.9 & +10.4 & +3.1 & -26 & -5.1 \\
\hline & GW 258 & 26.9 & +7.9 & +3.3 & -28 & -5.2 \\
\hline & GW 273 & 9.59 & +10.2 & +3.5 & -24 & -4.6 \\
\hline & GW 284 & 74.3 & & +4.7 & -27 & -5.2 \\
\hline & GW 285 & 39.4 & & +3.7 & -20 & -3.9 \\
\hline \multirow[t]{24}{*}{ Malta MSL } & GW 228 & 32.7 & +10.5 & +3.7 & -28 & -5.1 \\
\hline & GW 229 & 13.0 & +11.3 & +6.1 & -28 & -5.1 \\
\hline & GW 230 & 12.0 & +13.2 & +5.7 & -27 & -5.1 \\
\hline & GW 231 & 9.47 & +10.6 & +5.0 & -27 & -4.9 \\
\hline & GW 232 & 8.93 & +11.0 & +5.2 & -27 & -5.0 \\
\hline & GW 233 & 8.27 & +8.4 & +4.0 & -28 & -5.2 \\
\hline & GW 238 & 22.9 & +10.0 & +4.1 & -26 & -4.8 \\
\hline & GW 239 & 16.0 & +8.7 & +4.4 & -28 & -5.1 \\
\hline & GW 240 & 10.1 & +7.9 & +4.3 & -26 & -4.9 \\
\hline & GW 243 & 16.7 & +9.3 & +5.4 & -25 & -4.6 \\
\hline & GW 244 & 14.1 & +9.2 & +3.6 & -27 & -4.9 \\
\hline & GW 245 & 10.6 & & & -26 & -4.9 \\
\hline & GW 246 & 10.3 & +7.2 & +4.2 & -26 & -4.7 \\
\hline & GW 247 & 11.8 & +8.7 & +4.8 & -21 & -4.0 \\
\hline & GW 259 & 15.4 & +8.8 & +4.4 & -28 & -5.1 \\
\hline & GW 260 & 31.7 & +10.0 & +3.5 & -27 & -5.1 \\
\hline & GW 261 & 39.1 & +9.5 & +4.7 & -25 & -4.6 \\
\hline & GW 262 & 21.5 & +10.8 & +4.8 & -23 & -4.4 \\
\hline & GW 263 & 10.7 & +7.7 & +3.4 & -26 & -4.9 \\
\hline & GW 272 & 17.4 & +11.7 & +3.7 & -24 & -4.5 \\
\hline & GW 274 & 14.0 & +9.6 & +3.3 & -25 & -4.8 \\
\hline & GW 281 & 24.9 & +11.7 & +4.1 & -18 & -3.4 \\
\hline & GW 282 & 2.26 & +22.2 & +12.4 & -28 & -5.3 \\
\hline & GW 283 & 35.7 & +15.1 & +6.6 & -23 & -4.4 \\
\hline Gozo MSL & GW 248 & 13.0 & +10.0 & +4.6 & -26 & -4.9 \\
\hline
\end{tabular}




\begin{tabular}{lccccc} 
GW 249 & 15.0 & +9.6 & +3.1 & -27 & -5.1 \\
GW 250 & 8.99 & +7.8 & +4.8 & -25 & -4.8 \\
GW 251 & 19.7 & +11.6 & +5.3 & -26 & -5.0 \\
GW 252 & 8.58 & +9.6 & +6.4 & -25 & -4.8 \\
GW 253 & 9.86 & +7.6 & +3.0 & -27 & -5.1 \\
GW 254 & 8.17 & +8.3 & +4.5 & -25 & -4.8 \\
GW 255 & 6.60 & +8.4 & +4.9 & -27 & -5.1 \\
GW 275 & 11.8 & +10.7 & +3.8 & -28 & -5.3 \\
GW 276 & 23.6 & +10.3 & +3.1 & -26 & -4.9 \\
GW 277 & 10.1 & +11.6 & +4.7 & -25 & -4.9 \\
GW 278 & 6.60 & +10.5 & +6.1 & -25 & -4.7 \\
GW 279 & 5.46 & +8.4 & +2.8 & -26 & -4.9 \\
GW 280 & 19.8 & +12.3 & +5.2 & -26 & -4.9 \\
\hline
\end{tabular}


Table 3. Isotope composition of some of the fertilizers used in Malta

\begin{tabular}{llccc}
\hline Sample no. & Composition $^{\text {a }}$ & $\delta^{15} \mathrm{~N}_{\mathrm{NH} 4}(\%)$ & $\delta^{15} \mathrm{~N}_{\mathrm{NO} 3}(\%)$ & $\delta^{18} \mathrm{O}_{\mathrm{NO} 3}(\%)$ \\
\hline MF02 & Mono-ammonium phosphate & 0.0 & & \\
MF03 & Ammonium sulfate & -1.0 & & \\
MF04 & $12-6-36$ & -0.7 & +2.0 & +25.7 \\
MF05 & $14-14-28$ & -0.8 & +1.5 & +25.8 \\
MF06 & $18-9-26$ & -1.7 & +1.4 & +24.9 \\
MF07 & $18-18-18$ & -5.0 & & \\
MF08 & $19-5-30$ & -3.5 & +1.3 & +24.8 \\
MF09 & $23-12-12$ & -2.4 & & \\
MF10 & Potassium nitrate & & +3.5 & +24.2 \\
MF11 & $12-12-17+\mathrm{S}$ & +0.3 & +1.5 & +24.5 \\
\hline
\end{tabular}

${ }^{\text {a }}$ Numeric compositions (e.g. 12-6-36) refer to percentage of elemental N, P and K respectively. 
Table 4. Ammonium concentration, and ammonium and water isotope composition in sewage and animal wastes

\begin{tabular}{|c|c|c|c|c|c|c|c|}
\hline Type & Sample no. & Source & $\mathrm{NO}_{3}-\mathrm{N}\left(\mathrm{mg} \mathrm{kg}^{-1}\right)^{\mathrm{a}}$ & $\mathrm{NH}_{4}-\mathrm{N}\left(\mathrm{mg} \mathrm{kg}^{-1}\right)^{\mathrm{b}}$ & $\delta^{15} \mathrm{~N}_{\mathrm{NH} 4}(\% 0)$ & $\delta^{2} \mathrm{H}_{\mathrm{H} 2 \mathrm{O}}(\% 0)$ & $\delta^{18} \mathrm{O}_{\mathrm{H} 2 \mathrm{O}}(\%)$ \\
\hline \multirow[t]{8}{*}{ Sewers } & SW 266 & Domestic & 0.17 & 61 & +6.5 & -1 & -0.4 \\
\hline & SW 267 & Marsa sewage works (land side) & $<0.05$ & 97 & +6.3 & -13 & -2.8 \\
\hline & SW 268 & Marsa sewage works (coastal zone) & $<0.05$ & 82 & +5.4 & -10 & -2.1 \\
\hline & SW 269 & Domestic & 0.47 & 79 & +6.4 & -8 & -1.9 \\
\hline & SW 270 & Mixed domestic/animal & 0.18 & 61 & +6.9 & -11 & -2.3 \\
\hline & SW 271 & Industrial & $<0.05$ & 39 & +5.5 & -14 & -2.8 \\
\hline & SW 286 & Domestic & $<0.05$ & 43 & +6.5 & & \\
\hline & SW 287 & Domestic & $<0.05$ & 80 & +6.8 & & \\
\hline \multirow[t]{2}{*}{ Cesspits } & SW 288 & Domestic & $<0.05$ & 120 & +6.1 & & \\
\hline & SW 289 & Domestic & & 37 & +6.5 & & \\
\hline \multirow[t]{5}{*}{ Liquid animal waste } & SW 290 & Pigs & & 3600 & +5.1 & & \\
\hline & SW 291 & Pigs & & 1500 & +3.7 & & \\
\hline & SW 292 & Cattle & & 1700 & +3.1 & & \\
\hline & SW 293 & Pigs & & 1800 & +3.7 & & \\
\hline & SW 294 & Pigs & & 1300 & +6.4 & & \\
\hline \multirow[t]{6}{*}{ Manure (solid animal waste) } & SW 682 & Poultry & & 6200 & +9.8 & & \\
\hline & SW 683 & Cattle & & 1500 & +10.1 & & \\
\hline & SW 684 & Poultry & & 3300 & +2.3 & & \\
\hline & SW 685 & Cattle & & 950 & +6.1 & & \\
\hline & SW 686 & Poultry & & 3900 & +2.1 & & \\
\hline & SW 687 & Cattle & & 1300 & +5.9 & & \\
\hline
\end{tabular}


Table 5. Concentration and isotope composition of soil nitrogen

\begin{tabular}{|c|c|c|c|c|c|c|c|}
\hline & Sample no. & Location & Type & Crop & Organic-C (\%) ${ }^{\mathrm{a}}$ & Organic-N (\%) ${ }^{\mathrm{a}}$ & $\delta^{15} \mathrm{~N}_{\mathrm{ORG}}(\%)$ \\
\hline \multirow[t]{14}{*}{ Cultivated } & G 003 & Gozo & Vertisol & Summer crops & & & +6.3 \\
\hline & G 046 & Gozo & Vertisol & Cereal & & & +11.2 \\
\hline & G 053 & Gozo & Calcisol & Cereal & & & +10.5 \\
\hline & G 088 & Malta & Vertisol & Fodder & & & +6.0 \\
\hline & G 120 & Malta & Calcisol & Fruit trees & 6.6 & 0.70 & +8.2 \\
\hline & G 144 & Malta & Cambisol & Fallow & 1.2 & 0.15 & +8.4 \\
\hline & G 164 & Malta & Regosol & Vines & 4.1 & 0.44 & +7.8 \\
\hline & G 174 & Malta & Vertisol & Fallow & & & +8.6 \\
\hline & G 199 & Malta & Calcisol & Fallow & 3.7 & 0.39 & +9.3 \\
\hline & G 223 & Malta & Regosol & Fallow & 8.8 & 0.86 & +11.2 \\
\hline & G 236 & Malta & Leptosol & Vines & 4.3 & 0.50 & +8.8 \\
\hline & G 244 & Malta & Regosol & Fruit trees & 4.0 & 0.37 & +10.3 \\
\hline & G 276 & Malta & Calcisol & Fodder & 3.4 & 0.34 & +10.7 \\
\hline & G 308 & Malta & Calcisol & Fallow & 4.7 & 0.47 & +10.6 \\
\hline \multirow[t]{3}{*}{ Uncultivated or abandoned } & G 020 & Gozo & Vertisol & & & & +3.9 \\
\hline & G 028 & Gozo & Calcisol & & & & +7.2 \\
\hline & G 080 & Malta & Vertisol & & 4.3 & 0.43 & +5.3 \\
\hline
\end{tabular}

${ }^{\mathrm{a}} \% \mathrm{~N}$ in carbonate-free soil 


\section{FIGURE CAPTIONS}

\section{Figure 1}

Schematic cross-section through Malta (main island), showing the 'Perched' aquifer above the low permeability Blue Clay, and the 'Mean Sea Level' aquifer - a

Ghyben-Herzberg lens of fresh water floating on sea-water.

\section{Figure 2}

Cumulative frequency plot of nitrate concentrations in the Gozo Mean Sea Level aquifer, Malta Mean Sea Level aquifer, and Malta perched aquifers

\section{Figure 3}

Locations and nitrate concentrations of sampled groundwaters

\section{Figure 4}

${ }^{15} \mathrm{~N} /{ }^{14} \mathrm{~N}$ and ${ }^{18} \mathrm{O} /{ }^{16} \mathrm{O}$ ratios of nitrate in the different aquifers. The broken line in $\mathrm{b}$ is drawn with a $\delta^{15} \mathrm{~N}: \delta^{18} \mathrm{O}$ slope of $2: 1$

\section{Figure 5}

Solid circles show the measured ${ }^{15} \mathrm{~N} /{ }^{14} \mathrm{~N}$ and ${ }^{18} \mathrm{O} /{ }^{16} \mathrm{O}$ ratios of nitrate in Maltese groundwaters (all aquifers, excluding two denitrifed samples), and are compared with grey boxes showing probable ${ }^{15} \mathrm{~N} /{ }^{14} \mathrm{~N}$ and ${ }^{18} \mathrm{O} /{ }^{16} \mathrm{O}$ ratios of: (a) fertilizer, sewage and manure sources of nitrate; (b) soil sources of nitrate. 


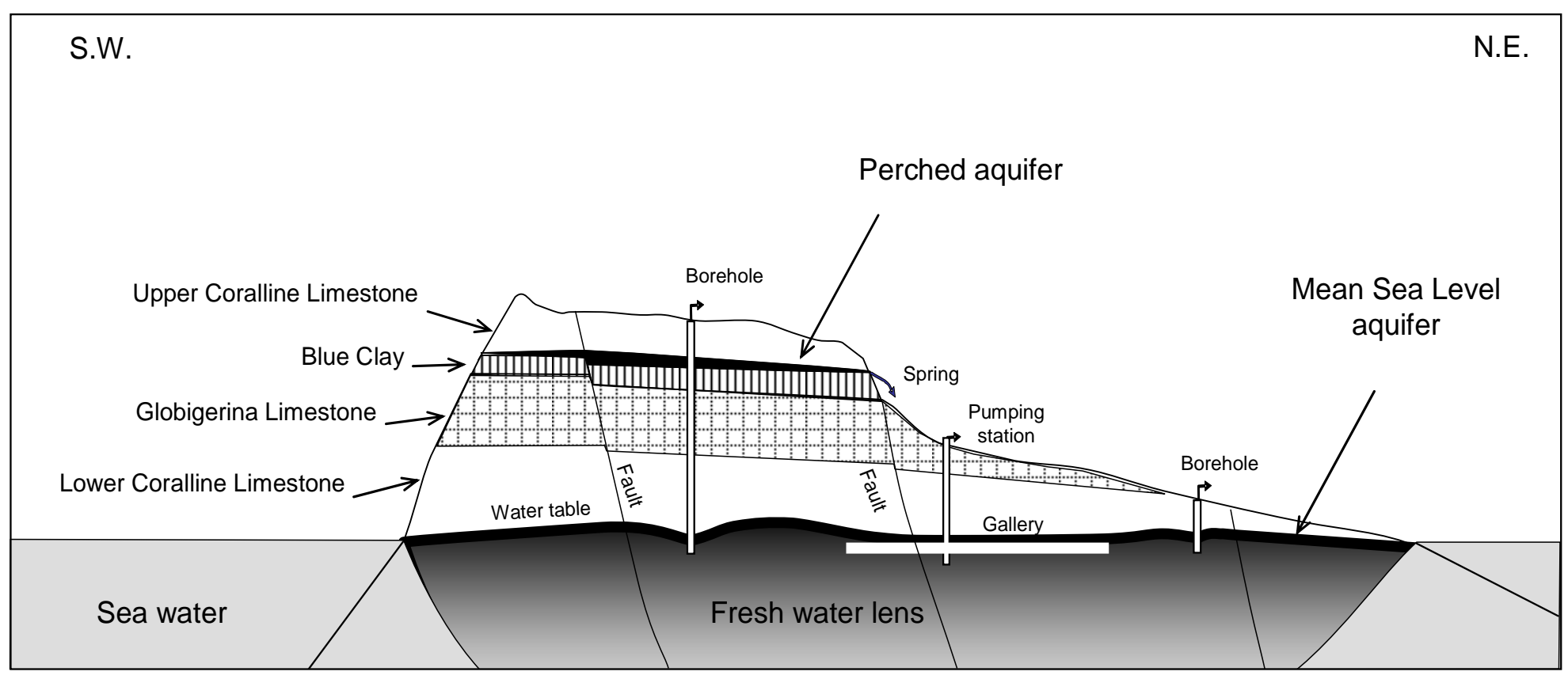

Figure 1 


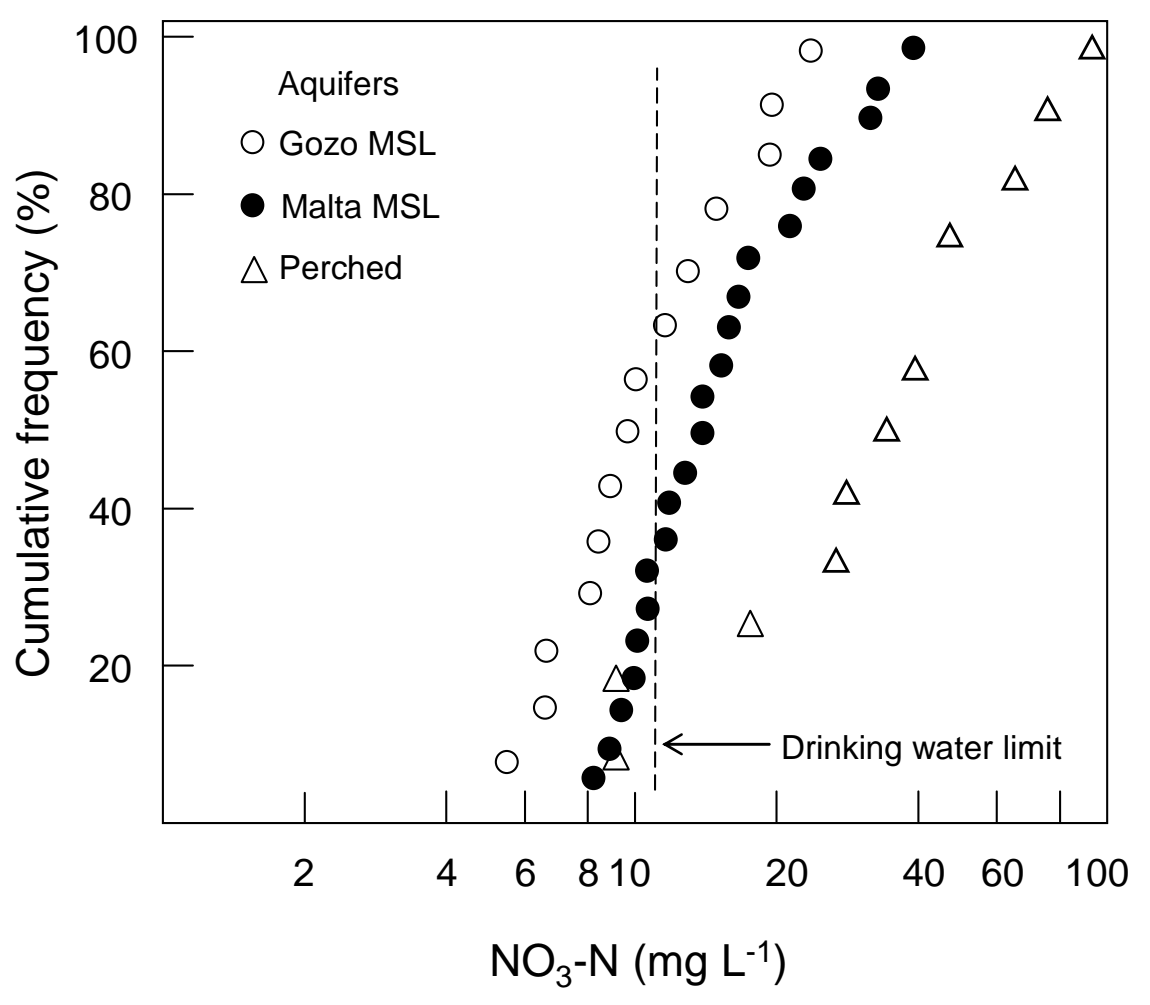

Figure 2 


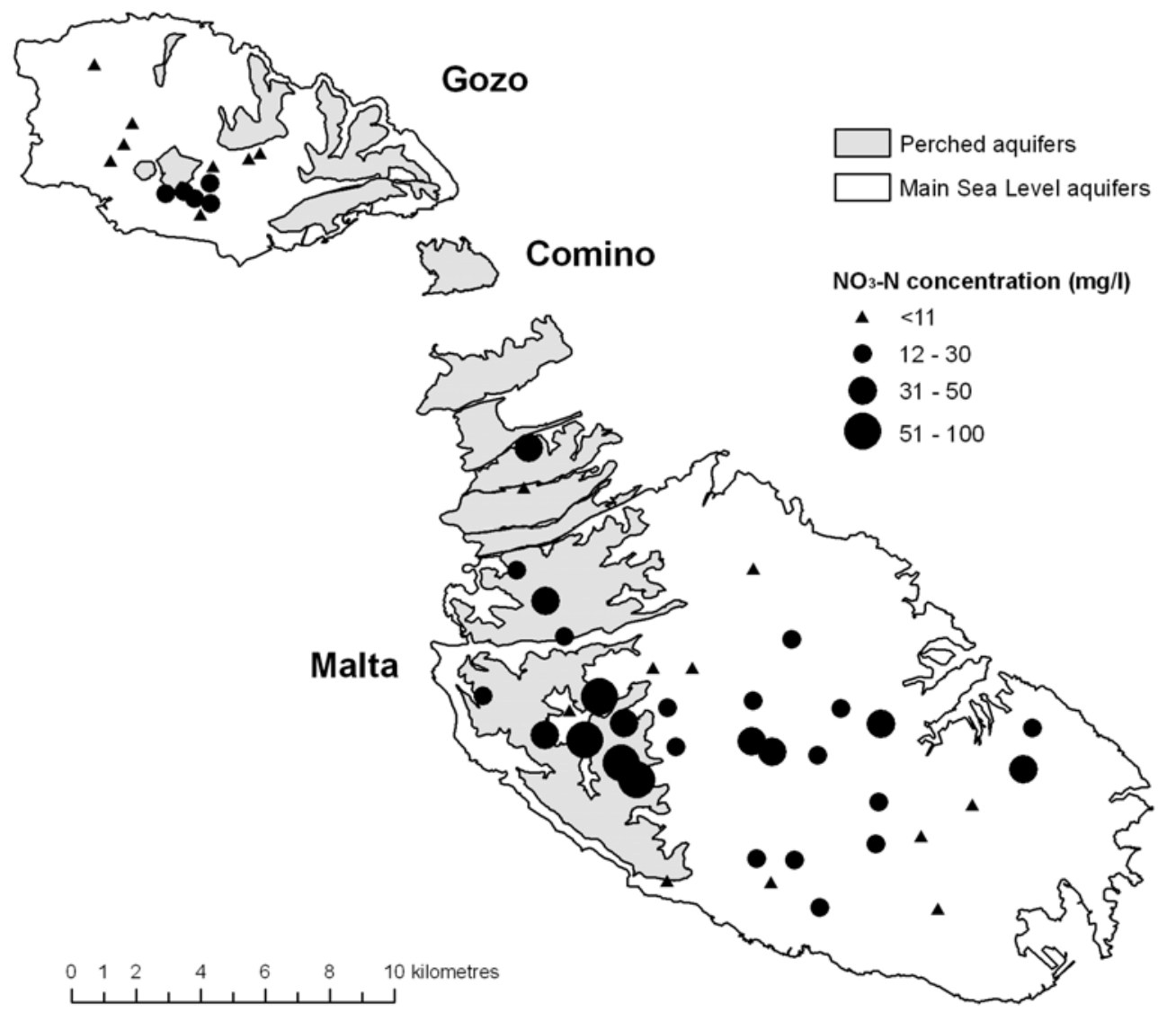

Figure 3 

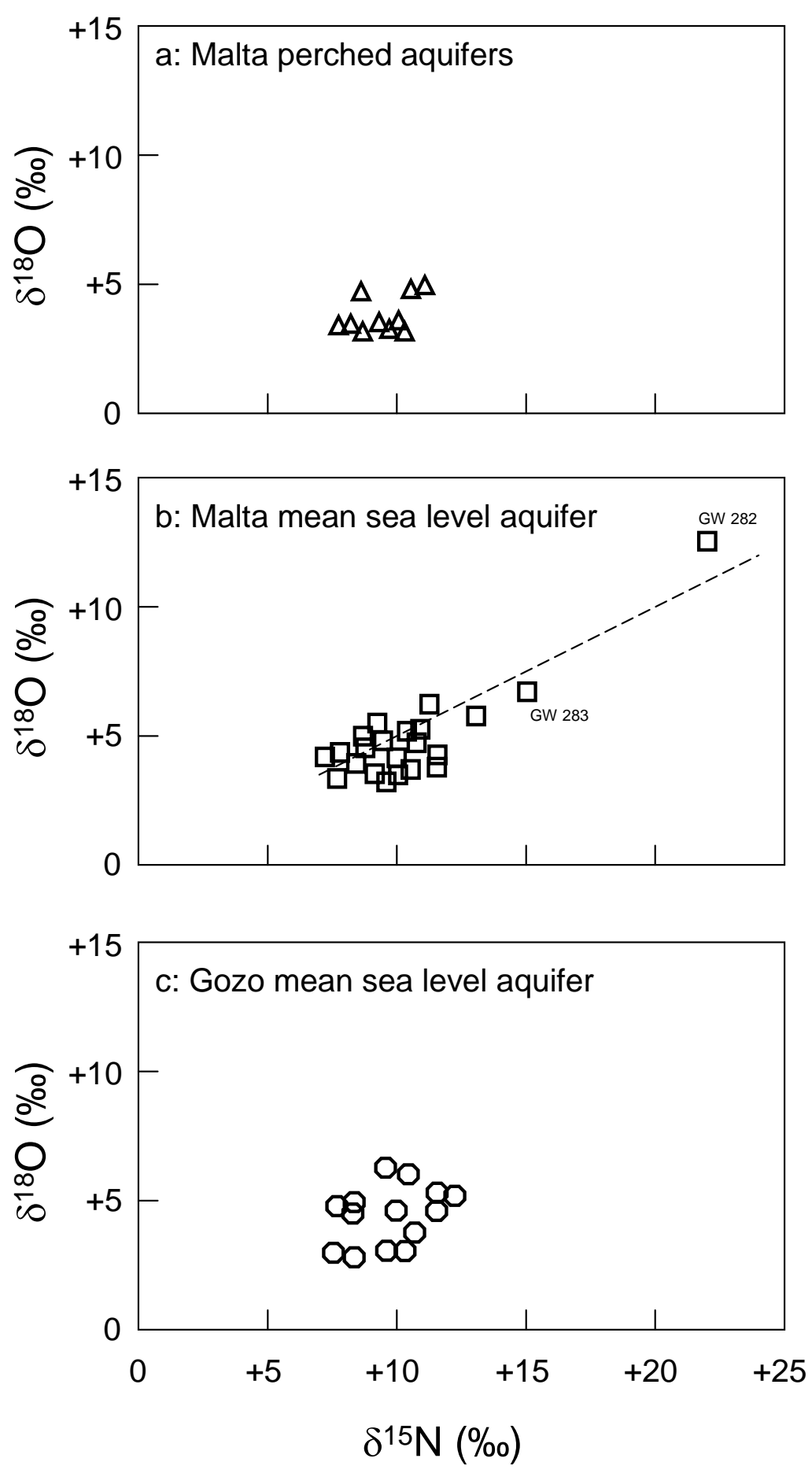

Figure 4 

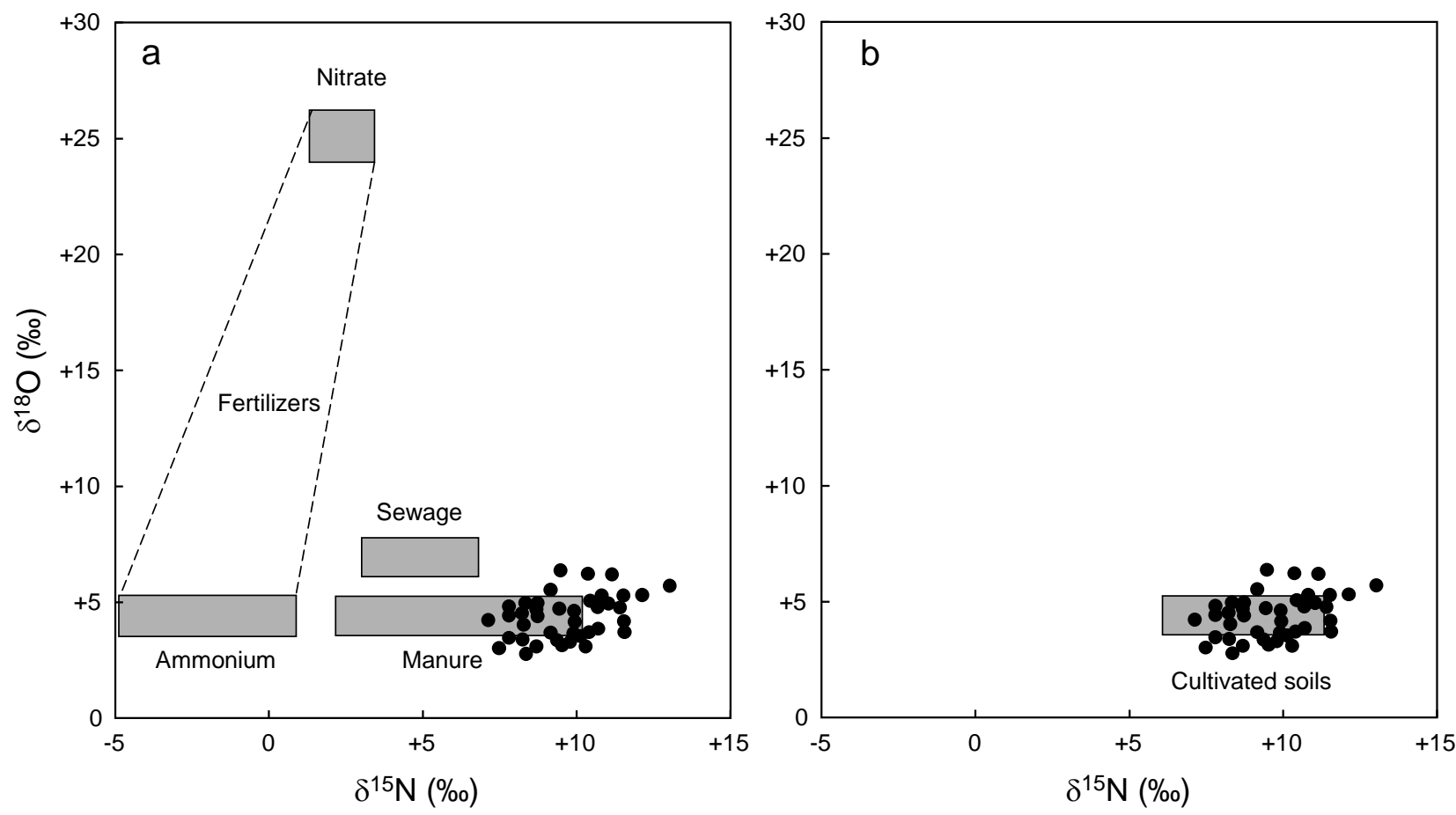

Figure 5 